\title{
PENGARUH GAYA KEPEMIMPINAN KEPALA PUSKESMAS TERHADAP KINERJA TENAGA KESEHATAN DI PUSKESMAS PEUREULAK BARAT
}

\author{
Usman $^{1}$, Muhammad Badiran ${ }^{2}$, Iman Muhammad ${ }^{3}$ \\ ${ }^{1,2,3}$ Fakultas Kesehatan Masyarakat Institut Kesehatan Helvetia Medan \\ Email : usmanplkb@gmail.com ${ }^{1}$, red.skrip@outlook.com ${ }^{2}$, \\ imanmuhammadhelvetia@gmail.com ${ }^{3}$
}

\begin{abstract}
Nowadas, leadership is the core of economic development in the Asian region including Indonesia. There are two dominant leadership styles, namely the American (western) style and the Asian (eastern) style of leadership. Based on preliminary survey, it shown the leader's style interact with subordinates, but the style is not used properly so that it is seen in 10 health workers in West Peureulak Health Centre, 6 of them have low performance. The purpose of this study was to determine the influence of the leadership style of the health centre head on the performance of health workers at the West Peureulak Health Centre in East Aceh Regency in 2018. The study used Cross-Sectional approach. The population in this study were 52 health workers and the sample taken by total sampling was 51 health workers. Data collection methods are primary data and secondary data. Analysis of the data used is binary logistic regression test. The results showed that the transactional leadership style has a sig pvalue $=.016<.05$, transformational $p$-value $=.005<.05$ and a situational leadership style has a $p$-value $=.003<.05$ which means that all leadership styles have an influence on the quality health services, while care has no influence on the performance of health workers. The conclusion is the influence of transactional, transformational and situational leadership styles on the performance of health workers found. It is expected to cadres in health centre to get more understand the importance of appropriate leadership styles in order to optimally improve the performance of health workers.
\end{abstract}

Keywords: leadership style, performance, situational, transactional, transformational

\section{PENDAHULUAN}

Kesehatan mempunyai peranan besar dalam meningkatkan derajat hidup masyarakat. Karena itu semua Negara berupaya menyelenggarakan pelayanan kesehatan yang sebaik-baiknya. Pelayanan kesehatan ini berarti setiap upaya yang diselenggarakan sendiri atau bersama-sama dalam suatu organisasi untuk memelihara dan meningkatkan kesehatan, mencegah dan mengobati penyakit, serta memulihkan kesehatan perseorangan, kelompok ataupun masyarakat. Untuk meningkatkan pelayanan kesehatan dalam suatu rumah sakit sendiri dibutuhkan seorang pemimpin untuk mengatur segala yang akan ingin dicapai.

Pemimpin dan kepemimpinan merupakan seni dan keterampilan seseorang dalam memanfaatkan seseorang dalam memanfaatkan kekuasaannya untuk memengaruhi orang lain, agar melaksanakan aktivitas tertentu yang diarahkan pada tujuan yang telah ditetapkan. Dalam menghadapi berbagai situasi dan kondisi tertentu, seseorang pemimpin harus melakukan upaya perubahan karakter. Hal ini dikarenakan, 
perubahan karakter merupakan strategi memecahkan permasalahan yang dihadapi. Tanpa perubahan karakter integritas yang kukuh, daya tahan menghadapi kesulitan dan tantangan, visi serta misi yang jelas, seseorang tidak akan pernah menjadi pemimpin (Thoha, 2013).

Gaya kepemimpinan yang digunakan oleh negara Amerika sangat umum dalam praktek kepemimpinan di negara Asia termasuk Indonesia yang menerapkan pola hubungan kerja arahan dan perintah. Adapun gaya kepemimpinan partisipatif di Asia lebih melibatkan kerja sama setara yang erat dengan pimpinan dan sesama pekerja, dan hal ini berlaku lebih umum di kawasan Eropa. Berdasarkan hasil pengamatan yang seksama, terdapat sembilan kualitas kunci dalam diri seorang pemimpin yang sukses meningkatkan motivasi pekerja, tentunya tanpa mengenyampingkan faktor budaya, yakni: gairah, ketegasan, keyakinan, integritas, adaptasi, ketangguhan emosional, resonansi emosional, pengenalan diri dan kerendahan hati (Affif, 2013).

Dalam pencapaian tujuan perusahaan banyak unsur-unsur yang menjadi hal penting dalam pemenuhannya, diantaranya adalah unsur kepemimpinan atau pemimpin. Sumber daya yang telah tersedia jika tidak dikelola dengan baik maka tidak akan memperoleh tujuan yang telah direncanakan, sehingga peranan pemimipin sangat penting yang dapat mempergunakan wewenang dan kepemimpinannya untuk mencapai suatu tujuan. Dasarnya kepemimpinan merupakan gaya seorang pemimpin memengaruhi bawahannya agar mau bekerja sama dan bekerja efektif sesuai dengan perintahnya, dengan gaya kepemimpinan yang dimiliki oleh seorang pemimpin ini yang akan digunakan untuk bisa mengarahkan sumber daya manusia dapat menggunakan semua kemampuannya dalam mencapai motivasi kerja yang baik (Wahab, 2014).

Menurut teori Gibson yang dikutip Mangkunegara, kinerja seorang petugas sendiri dipengaruhi beberapa faktor diantaranya faktor internal yang meliputi kecerdasan, keterampilan, kestabilan emosi, sifat-sifat seseorang, meliputi sikap, sifat-sifat kepribadian, sifat fisik, keinginan atau motivasi, umur, jenis kelamin, pendidikan, pengalaman kerja, latar belakang budaya dan variabel-variabel personal lainnya. sedangkan faktor eksternal yang memengaruhi kinerja yaitu yang berasal dari lingkungan, meliputi peraturan ketenagakerjaan, keinginan pelanggan, pesaing, kondisi ekonomi, kebijakan organisasi, kepemimpinan, tindakan-tindakan rekan kerja jenis latihan dan pengawasan, sistem upah dan lingkungan sosial (Mangkunegara, 2014b). 
Menurut Mangkunegara, salah satu faktor yang memengaruhi kinerja ialah kepemimpinan yang termasuk dalam faktor organisasi. Kepemimpinan memiliki peran penting dalam organisasi, pimpinan bertugas untuk mengawasi serta mengontrol jalannya suatu organisasi. Sehingga peran pemimpin di lingkungan organisasi sangat vital serta memastikan organisasi berjalan dengan baik dan mencapai tujuan yang ditargetkan. Penggunaan kepemimpinan yang tepat dari atasan merupakan salah satu faktor yang dapat menggerakkan, mengarahkan, membimbing dan memotivasi pegawai untuk lebih berprestasi dalam bekerja. Seorang pemimpin harus mampu mengarahkan bawahannya untuk memiliki kompetensi dalam bekerja, karena dapat mendorong peningkatan kualitas kinerja (Mangkunegara, 2014b).

Secara psikologis, aspek yang sangat penting dalam kepemimpinan kerja adalah sejauhmana pimpinan mampu memengaruhi motivasi kerja SDM-nya agar mereka mampu bekerja produktif dengan penuh tanggung jawab dengan alasan karyawan harus didorong untuk bekerja sama dalam organisasi, karyawan harus senantiasa di dorong untuk bekerja dan berusaha sesuai dengan tuntutan kerja dan motaivasi karyawan merupakan aspek yang sangat penting dalam memelihara dan mengembangkan SDM dalam organisasi (Kontesa, 2014).

Peningkatan kinerja karyawan akan membawa kemajuan bagi perusahaan untuk dapat bertahan dalam suatu pers. aingan lingkungan bisnis yang tidak stabil. Oleh karena itu upaya-upaya untuk meningkatkan kinerja karyawan merupakan tantangan manajemen yang paling serius karena keberhasilan untuk mencapai tujuan dan kelangsungan hidup perusahaan tergantung pada kualitas kinerja sumber daya manusia yang ada didalamnya. Kinerja karyawan yang tinggi sangatlah diharapkan oleh sebuah organisasi atau instansi. Semakin banyak karyawan yang mempunyai kinerja tinggi, maka produktivitas instansi secara keseluruhan akan meningkat sehingga organisasi atau instansi akan dapat bertahan dalam persaingan global. Peranan seorang pemimpin penting untuk mencapai tujuan organisasi atau instansi terutama berkaitan dengan peningkatan kinerja pegawai dalam melaksanakan pekerjaannya. Kinerja pegawai merupakan hasil kerja yang dapat dicapai seseorang atau sekelompok orang dalam suatu organisasi atau instansi sesuai wewenang dan tanggung jawab masingmasing dalam rangka mewujudkan tujuan organisasi (Wahab, 2014).

Kinerja karyawan yang tinggi sangatlah diharapkan oleh sebuah organisasi 
atau instansi. Semakin banyak karyawan yang mempunyai kinerja tinggi, maka produktivitas instansi secara keseluruhan akan meningkat sehingga organisasi atau instansi akan dapat bertahan dalam persaingan global. Peranan seorang pemimpin penting untuk mencapai tujuan organisasi atau instansi terutama berkaitan dengan peningkatan kinerja pegawai dalam melaksanakan pekerjaannya (Kontesa, 2014).

Berdasarkan penelitian yang dilakukan oleh Nurmawilis, menunjukkan bahwa untuk meningkatkan kinerja karyawan di RSUD Rokan Hulu dianjurkan untuk meningkatkan efektivitas gaya kepemimpinannya terutama pada aspek memberikan perhatian pada karyawan baru, menemukan keinginan karyawan serta memberikan informasi mengenai organisasi dan pihak rumah sakit juga harus lebih memperhatikan faktor kepuasan kerja karyawannya terutama dalam aspek memberikan kebijakan promosi, penghargaan terhadap keberhasilan tugas serta kesempatan untuk pertumbuhan dan pengembangan diri (Nurmawilis, 2010).

Berdasarkan survei awal yang dilakukan, terlihat bahwa gaya yang digunakan para pemimpin adalah interaksi pemimpin dengan bawahannya, namun gaya tersebut tidak digunakan dengan baik sehingga terlihat pada 10 tenaga kesehatan
Puskesmas Peureulak Barat, 6 tenaga kesehatan diantaranya memiliki kinerja yang rendah, hal ini terlihat dari tenaga kesehatan ada sering absen kerja, kerja yang setengah hati, pulang kerja tidak sesuai dengan jadwal yang ditentukan dan ada beberapa tenaga kesehatan yang bermalas-malasan dalam bekerja. Faktor yang membuat kinerja kerja kurang baik dikarenakan kepemimpinan kepala Puskesmas yang kurang memperhatikan keluhan-keluhan dari para tenaga kesehatan. Gaya kepemimpinan yang ada di Puskesmas Peureulak Barat yaitu pemimpin tidak pernah berkomunikasi dengan baik kepada bawahan, pemimpin tidak mau memperhatikan hasil kerja dari bawahan, pemimpin tidak mau membimbing bawahannya apabila bawahan tidak mengerti masalah dalam pekerjaannya, pemimpian tidak mau berbaur dengan bawahan, pemimpin terlalu kaku atau terlalu berwibawa kepada bawahannya dan pemimpin hanya mementingkan kepentingan pribadinya dibandingkan urusan pekerjaan, serta pemimpin terlalu arogan (marah-marah) ketika bawahan melakukan kesalahan.

Berdasarkan latar belakang di atas rumusan masalah penelitian ini adalah: apakah ada pengaruh gaya kepemimpinan kepala puskesmas terhadap kinerja tenaha kesehatan?. Tujuan penelitian ini untuk 
mengetahui pengaruh gaya kepemimpinan kepala puskesmas terhadap kinerja tenaga kesehatan.

\section{METODE PENELITIAN}

Desain penelitian menggunakan motode Survei Analitik yaitu meneliti bagaimana dan mengapa fenomena terjadi yang kemudian menganalisa hubungan antara fenomena tersebut sehingga dapat diketahui sejauh mana faktor resiko berpengaruh terhadap suatu kejadian. Penelitian ini menggunakan pendekatan cross sectional yaitu mempelajari hubungan antara faktor resiko dengan kejadian menggunakan metode observasi atau pengumpulan data dalam waktu yang bersamaan (Muhammad, 2015).

Penelitian ini dilakukan di Puskesmas Peureulak Barat Kabupaten Aceh Timur tahun 2018 dan penelitian dilaksanakan pada bulan Juli tahun 2018 sampai dengan bulan Desember 2018.

Populasi pada penelitian ini adalah seluruh tenaga kesehatan yang PNS di Puskesmas Peureulak Barat yaitu sebanyak 51 tenaga kesehatan dan teknik pengambilan sampel dalam penelitian ini adalah sampling total yaitu pengambilan sampel berdasarkan keseluruhan populasi yaitu sebanyak 51 tenaga kesehatan.

Analisis data yang digunakan yaitu analisis multivariat. Analisis Multivariat bertujuan untuk melihat kemaknaan korelasi antara variabel bebas (independent variable) dengan variabel terikat (dependent variable) di lokasi penelitian secara simultan dan sekaligus menentukan faktor yang lebih dominan berpengaruh terhadap kinerja karyawan. Uji statistik yang digunakan untuk analisis multivariat yaitu Regression Binary Logistic (Regresi Binari Logistik) pada batas kemaknaan 95\% dengan perhitungan statistik $\alpha=0,05$.

HASIL

Variabel gaya kepemimpinan transaksional memiliki nilai sig-p 0,016 < 0,05 artinya gaya kepemimpinan transaksional memiliki pengaruh secara signifikan terhadap kinerja tenaga kesehatan di Puskesmas Peureulak Barat Kabupaten Aceh Timur tahun 2018. Selanjutnya dari hasil nilai Odds Ratio (OR) variabel gaya kepemimpinan transaksional memiliki nilai OR 9,839 maka gaya kepemimpinan transaksional yang baik, memiliki pengaruh terhadap kinerja tenaga kesehatan sebanyak 9,839 kali lipat di bandingkan gaya kepemimpinan transaksional yang kurang.

\section{PEMBAHASAN}

Penelitian yang dilakukan oleh Hendrik, H tahun 2016 tentang Pengaruh Gaya Kepemimpinan Transaksional Terhadap Kinerja Karyawan (Studi Pada PT. Kumala Motor Sejahtera Abadi Kendari), menunjukkan bahwa gaya kepemimpinan 
transaksional berpengaruh signifikan dan positif terhadap kinerja karyawan. Artinya semakin baik implementasi gaya kepemimpinan transaksional yang dipersepsi dari imbalan kontingen, manajemen aktif dengan pengecualian dan hal yang tak campur tangan dapat memacu perbaikan kinerja karyawan yang terimplementasi pada perbaikan kualitas kerja, kuantitas kerja, ketepatan waktu, efektifitas, dan kemandirian (Hendrik, 2016).

Sejalan dengan penelitian yang dilakukan oleh Hartanto, I tahun 2014 tentang Pengaruh Gaya Kepemimpinan Transaksional terhadap Kinerja Karyawan dengan Kepuasan Kerja Sebagai Variabel Intervening pada CV. Timur Jaya, menunjukkan bahwa gaya kepemimpinan transaksional bepengaruh positif dan signifikan terhadap kepuasan kerja. Kepemimpinan transaksional merupakan model gaya kepemimpinan dengan cara memusatkan pada pencapaian tujuan atau sasaran, namun tidak berupaya mengembangkan tanggung jawab dan wewenang bawahan demi kemajuan bawahan (Hartanto, 2014).

Kepemimpinan transaksional merupakan salah satu gaya kepemimpinan yang intinya menekankan transaksi di antara pemimpin dan bawahan. Kepemimpinan transaksional memungkinkan pemimpin memotivasi dan memengaruhi bawahan dengan cara mempertukarkan reward dengan kinerja tertentu. Artinya, dalam sebuah transaksi bawahan dijanjikan untuk diberi reward bila bawahan mampu menyelesaikan tugasnya sesuai dengan kesepakatan yang telah dibuat bersama. Alasan ini mendorong Burns untuk mendefinisikan kepemimpinan transaksional sebagai bentuk hubungan yang mempertukarkan jabatan atau tugas tertentu jika bawahan mampu menyelesaikan dengan baik tugas tersebut. Jadi, kepemimpinan transaksional menekankan proses hubungan pertukaran yang bernilai ekonomis untuk memenuhi kebutuhan biologis dan psikologis sesuai dengan kontrak yang telah mereka setujui bersama (Munandar, 2011).

Menurut beberapa jawaban dari hasil wawancara didapatkan hasil bahwa gaya kepemimpinan transaksional merupakan gaya kepemimpinan yang memiliki pengaruh terhadap kinerja tenaga kesehatan. Hal ini dikarenakan pemimpin transaksional memperkenalkan apa yang diinginkan bawahan dari pekerjaannya dan mencoba memikirkan apa yang akan bawahan peroleh jika hasil kerjanya sesuai dengan transaksi. Pemimpin menjanjikan imbalan bagi usaha yang dicapai, dan pemimpin tanggap terhadap minat pribadi bawahan bila ia merasa puas dengan kinerjanya, dengan kata lain gaya 
kepemimpinan transaksional merupakan salah satu faktor penentu untuk meningkatkan kinerja tenaga kesehatan. Walaupun gaya kepemimpinan ini jarang digunakan, namun gaya kepemimpinan ini juga harus dimiliki oleh kepala puskesmas, dikarenakan gaya kepemimpinan ini dapat digunakan diwaktu tertentu seperti pada saat memberikan arahan dan bimbingan kepada petugas kesehatan dalam menyelesaikan pekerjaan dan memberikan kritik yang dapat membangun semangat petugas kesehatan dalam menyelesaikan pekerjaannya.

Variabel gaya kepemimpinan transformasional memiliki nilai sig- $p$ 0,005 $<0,05$ artinya gaya kepemimpinan transformasional memiliki pengaruh secara signifikan terhadap kinerja tenaga kesehatan di Puskesmas Peureulak Barat Kabupaten Aceh Timur tahun 2018. Selanjutnya dari hasil nilai Odds Ratio (OR) variabel gaya kepemimpinan transformasional dengan OR 12,918 maka gaya kepemimpinan transformasional yang baik, memiliki pengaruh terhadap kinerja tenaga kesehatan sebanyak 12,918 kali lipat dibandingkan gaya kepemimpinan transformasional yang kurang.

Penelitian yang dilakukan oleh Murtiningsih tahun 2015, tentang Pengaruh Gaya Kepemimpinan Transformasional pada Kinerja Perawat Rumah Sakit Islam
Siti Aisyah Madiun, menunjukkan bahwa kepemimpinan transformasional berpengaruh signifikan dan positif terhadap kinerja. Variabel kepemimpinan transformasional memiliki pengaruh yang signifikan terhadap kinerja, variabel kepercayaan pemimpin dan variabel kepuasan kerja memiliki peran sebagai variabel mediasi (Murtiningsih, 2015).

Sejalan dengan penelitian yang dilakukan oleh Muttaqin, L tahun 2016 tentang Pengaruh Gaya Kepemimpianan Transformasional dan Pengembangan SDM terhadap Kinerja Perawat RSJ Grhasia Yogyakarta, menunjukkan bahwa gaya kepemimpinan tranformasional berpengaruh positif dan signifikan terhadap kinerja perawat. Gaya kepemimpinan transformasional menjadikan para pengikut merasakan kepercayaan, kekaguman, kesetiaan dan penghormatan terhadap pemimpin dan mereka termotivasi untuk melakukan lebih daripada yang semula diharapkan dari mereka (Muttaqin, 2016).

Gaya kepemimpinan transformasional dan pengembangan SDM merupakan suatu hal yang tidak dapat diabaikan untuk memaksimalkan kinerja perawat. Penggunaan gaya kemimpinan yang tepat akan membuat organisasi semakin membuat bergairah. Adanya pimpinan yang menginspirasi bawahan dan memotivasi akan meningkatkan kinerja perawat. 
Sebagaian perawat mengakui kepala ruang belum memberikan sugesti postitif untuk meningkatkan motivasi. Pimpinan belum mengartikulasikan visi menarik kepada para perawat supaya timbul motivasi tinggi dalam bekerja dan memberikan dorongan terhadap apa yang perlu dilakukan sehingga akan meningkatkan kinerja perawat (Bangun, 2013).

Menurut hasil wawancara pada kepala Puskesmas menunjukkan bahwa gaya kepemimpinan transformasional memiliki pengaruh terhadap kinerja tenaga kesehatan. Hal ini dikarenakan pemimpin transformasional menginspirasi para pengikut untuk mengenyampingkan kepentingan pribadi mereka demi kebaikan organisasi dan pemimpin transformasional mampu memiliki pengaruh yang luar biasa pada diri para pengikut. Mengubah kesadaran para pengikut dengan cara membantu orang lain memandang masalah lama dengan cara yang baru dan dapat mengsinspirasikan para pengikut untuk bekerja keras guna mencapai tujuan-tujuan bersama. Dalam stimulasi intelektual, pemimpin transformasional meningkatkan kesadaran pengikut akan permasalahan dan memengaruhi para pengikut untuk memandang masalah dari perspektif yang baru. Dalam hal ini gaya kepemimpinan transformasional juga tidak selalu digunakan, namun gaya ini digunakan pada saat menegur tenaga kesehatan pada saat melakukan kesalahan dalam menyelesaikan pekerjaan dan memberikan perhatian kepada petugas kesehatan dalam menyelesaikan pekerjaannya. Gaya kepemimpinan ini bertujuan agar kepala puskesmas dapat menyampaikan teguran dan arahan yang tidak menyinggung perasaan petugas kesehatan dan menciptakan suasana kerja yang harmonis.

Variabel gaya kepemimpinan situasional memiliki nilai sig-p $0,003<$ 0,05 artinya gaya kepemimpinan situasional memiliki pengaruh secara signifikan terhadap kinerja tenaga kesehatan di Puskesmas Peureulak Barat Kabupaten Aceh Timur tahun 2018. Selanjutnya dari hasil nilai Odds Ratio (OR) Variabel gaya kepemimpinan situasional dengan OR 21,081 maka gaya kepemimpinan situasional yang baik, memiliki pengaruh terhadap kinerja tenaga kesehatan sebanyak 21,081 kali lipat di bandingkan gaya kepemimpinan situasional yang kurang.

Penelitian yang dilakukan oleh Dermawan P tahun 2018, tentang Pengaruh Gaya Kepemimpinan Situasional Terhadap Kinerja Karyawan Dengan Motivasi Kerja Sebagai Variabel Intervening (Studi Pada PT Anugerah Sinergi Raya), menunjukkan bahwa gaya Kepemimpinan situasional memiliki pengaruh positif dan signifikan terhadap motivasi kerja, variabel Gaya 
Kepemimpinan Situasional memiliki pengaruh positif dan signifikan terhadap kinerja karyawan, variabel motivasi kerja memiliki pengaruh positif dan signifikan terhadap kinerja karyawan, dan motivasi kerja memediasi pengaruh antara gaya kepemimpinan situasional terhadap kinerja karyawan. Kesimpulan dari penelitian ini menunjukkan Gaya Kepemimpinan Situasional memiliki pengaruh pada kinerja karyawan dengan motivasi kerja sebagai variabel intervening. Hal tersebut menunjukkan semakin tinggi gaya kepemimpinan situasional akan berdampak positif pada motivasi kerja dan peningkatan kinerja karyawan (Dermawan, 2018).

Sejalan dengan penelitian yang dilakukan oleh Putra, I tahun 2017 tentang Pengaruh Gaya Kepemimpinan Situasional dan Motivasi Kerja terhadap Kepuasan Kerja Karyawan (Studi Pada Alpha Hotel Pekanbaru), menunjukkan bahwa kepemimpinan situasional dan motivasi kerja mempunyai pengaruh yang signifikan, karena penerapan Gaya kepemimpinan situasional yang baik dan motivasi yang diberikan juga baik akan menghasilkan karyawan yang puas terhadap pekerjaanya sehingga tujuan dari perusahaan tersebut tercapai (Putra, 2017).

Gaya kemimpinan situasional terdiri dari empat gaya dasar kepemimpinan yaitu, gaya instruksi, konsultasi, partisipasi, dan delegasi. Melalui keempat gaya dasar kepemimpinan situasional tersebut pemimpin dapat memilih cara yang paling cocok digunakan untuk membimbing pengikutnya melalui situasi yang sedang terjadi di dalam perusahaan. Semua gaya kepemimpinan yang digunakan pemimpin semata-mata hanya untuk memberikan motivasi kepada bawahan agar meningkatkan kinerjanya (Thoha, 2013).

Berdasarkan beberapa teori di atas dapat disimpulkan bahwa kinerja merupakan tingkat keberhasilan seseorang yang dicapai sesuai dengan tanggung jawab yang diterimanya. Ada dua faktor yang memengaruhi kinerja karyawan yaitu, faktor kemampuan yang terdiri dari kemampuan potensi (IQ) dan kemampuan realita (knowledge+skill), dan motivasi terbentuk dari sikap (attitude). Oleh karena itu, dapat disimpulkan bahwa kinerja karyawan sangat berhubungan dengan motivasi yang diberikan kepada karyawan (Mangkunegara, 2014a).

Menurut hasi wawancara kepala Puskesmas, kepemimpinan situasional memiliki pengaruh terhadap kinerja tenaga kesehatan. Hal ini dikarenakan pemimpin dapat menjadi seorang panutan yang dapat ditiru perilakunya, terkadang pemimpin tersebut dapat menjadi seorang teman dimana tenaga kesehatan dapat berkomunikasi dua arah secara terbuka. 
Maka dari itu diperlukan kerjasama antara pemimpin dengan bawahan maupun kerjasama tim yang akan meningkatkan kualitas kerja perusahaan dengan lebih baik lagi dari waktu ke waktu.

Berdasarkan kesimpulan tentang ketiga gaya kepemimpinan menunjukkan bahwa, ketiga gaya ini harus dapat dimiliki seseorang kepala Puskesmas. Hal ini dikarenakan ketiga gaya ini dapat membantu untuk meningkatkan kerja tenaga kesehatan di Puskesmas, namun ketiga gaya ini tidak dapat dipakai sekaligus pada pemimpin, tetapi ketiga gaya ini dapat dipalikasikan satu per satu pada saat waktu tertentu sesuai dengan keadaan yang tepat dalam menghadapi dan memberik arahan kepada tenaga kesehatan, sebagai contoh gaya kepemimpinan transaksional digunakan pada saat memberikan arahan dan bimbingan pada tenaga kesehatan yang belum memahami secara jelas tugas yang akan dilakukan serta memberikan kritik yang membangun pada saat tenaga kesehatan memiliki hasil kerja yang kurang memuaskan. Selanjutnya gaya kepemimpinan transformasional digunakan pada saat tenaga kesehatan melakukan kesalahan pada saat bekerja dengan cara menegurnya secara lembut serta pada saat tenaga kesehatan bekerja pemimpin selalu memberikan perhatiannya kepada tenaga kesehatan dengan cara melihat dan mengawasi pekerjaan yang dilakukan. Begitu juga gaya situasional yang dapat digunakan pada saat pengambilan keputusan masalah pekerjaan, tenaga kesehatan yang tidak optimis dalam menyelesaikan pekerjaan dan pada saat tenaga kesehatan tidak bekerja sesuai dengan standar pekerjaan yang telah ditetapkan.

\section{KESIMPULAN}

Kesimpulan dalam penelitian ini menunjukkan bahwa ada pengaruh gaya kepemimpinan, transaksional, transformasional dan situasional dengan kinerja tenaga kesehatan di Puskesmas Peureulak Barat Kabupaten Aceh Timur tahun 2018.

\section{SARAN}

Hasil penelitian ini diharapkan dapat memberikan gambaran tentang kualitas kepemimpinan yang maksimal untuk meningkatkan kualitas kinerja tenaga kesehatan di Puskesmas sehingga dapat dijadikan dasar untuk mengambil suatu kebijakan lebih lanjut.

\section{DAFTAR PUSTAKA}

Affif, M. (2013). Gaya Kepemimpinan Amerika dan Asia. Bandung: Universitas Padjajaran.

Bangun, R. D. (2013). Pengaruh Gaya Kepemimpinan Transformasional Kepala Ruang dan Motivasi Intrinsik Perawat Pelaksana Kontrak Terhadap Kinerja Perawat Pelaksana Kontrak di Ruang Rawat Inap RSUD Dr. Pirngadi Medan. Medan: Tesis Pascasarjana 
Universitas Sumatera Utara.

Dermawan, P. (2018). Pengaruh Gaya Kepemimpinan Situasional Terhadap Kinerja Karyawan Dengan Motivasi Kerja Sebagai Variabel Intervening (Studi Pada PT Anugerah Sinergi Raya). 60(2), 95-104.

Hartanto, I. (2014). Pengaruh Gaya

Kepemimpinan Transaksional

Terhadap Kinerja Karyawan Dengan

Kepuasan Kerja Sebagai Variabel Intervening Pada CV. Timur Jaya. Agora, 2(2).

Hendrik, H. (2016). Pengaruh Gaya Kepemimpinan Transaksional terhadap Kinerja Karyawan (Studi Pada PT. Kumala Motor Sejahtera Abadi Kendari). Skripsi.

Kontesa, R. (2014). Hubungan Gaya Kepemimpinan Kepala Ruangan dengan Motivasi Kerja Perawat di Ruang Rawat Inap Rumah Sakit Umum Daerah DR. Rasidin Padang. Padang: Skripsi UNP.

Mangkunegara. (2014a). Evaluasi Kinerja SDM. Bandung: Refika Aditama.

Mangkunegara. (2014b). Manajemen Sumber Daya Manusia. Bandung: PT. Remaja Rosdakarya.

Muhammad, I. (2015). Panduan penyusunan Karya Tulis Ilmiah Bidang Kesehatan Menggunakan Metode Ilmiah. Bandung: Cita Pustaka Media Perintis.

Munandar, U. (2011). Psikologi Industri dan Organisasi. Jakarta: UI.

Murtiningsih. (2015). Pengaruh Gaya Kepemimpinan Transformasional Pada Kinerja Perawat Rumah Sakit Islam Siti Aisyah Madiun. Jurnal Ekonomi Manajemen Sumber Daya, 17(2), 54-65.

Muttaqin, L. Z. (2016). Pengaruh Gaya
Kepemimpinan Transformasional dan Pengembangan SDM Terhadap Kinerja Perawat RSJ Grhasia Yogyakarta. (June), 1-138.

Nurmawilis, N. (2010). Pengaruh Gaya Kepemimpinan dan Kepuasan Kerja terhadap Kinerja Karyawan di RSUD Rokan Hulu Riau. Medan: Tesis Universitas Sumatera Utara.

Putra, I. P. (2017). Pengaruh Gaya Kepemimpinan Situasional dan Motivasi Kerja terhadap Kepuasan Kerja Karyawan (Studi Pada Alpha Hotel Pekanbaru). JOM FISIP, 4(2), $1-7$.

https://doi.org/10.1017/CBO9781107 415324.004

Thoha, M. (2013). Kepemimpinan dalam Manajemen. Jakarta: Rajawali Pers.

Wahab, A. A. (2014). Organisasi dan Kepemimpinan Pendidikan. Bandung: Alfabeta. 